\title{
Presynaptic Versus Postsynaptic Localization of $\mu$ and $\delta$ Opioid Receptors in Dorsal and Ventral Striatopallidal Pathways
}

\author{
M. Foster Olive, ${ }^{1,2}$ Benito Anton, ${ }^{2}$ Paul Micevych, ${ }^{3}$ Christopher J. Evans, ${ }^{2}$ and Nigel T. Maidment ${ }^{2}$ \\ $1 /$ nterdepartmental Neuroscience Ph.D. Program and Departments of ${ }^{2} P$ sychiatry and Biobehavioral Sciences and \\ ${ }^{3}$ Neurobiology, University of California at Los Angeles, Los Angeles, California 90024
}

\begin{abstract}
Parallel studies have demonstrated that enkephalin release from nerve terminals in the pallidum (globus pallidus and ventral pallidum) can be modulated by locally applied opioid drugs. To investigate further the mechanisms underlying these opioid effects, the present study examined the presynaptic and postsynaptic localization of $\delta$ (DOR1) and $\mu$ (MOR1) opioid receptors in the dorsal and ventral striatopallidal enkephalinergic system using fluorescence immunohistochemistry combined with anterograde and retrograde neuronal tracing techniques. DOR1 immunostaining patterns revealed primarily a postsynaptic localization of the receptor in pallidal cell bodies adjacent to enkephalin- or synaptophysin-positive fiber terminals. MOR1 immunostaining in the pallidum revealed both a presynaptic localization, as evidenced by punctate staining that co-localized with enkephalin and synaptophysin, and a postsynaptic localization, as evidenced by cytoplasmic staining
\end{abstract}

of cells that were adjacent to enkephalin and synaptophysin immunoreactivities. Injections of the anterograde tracer Phaseolus vulgaris leucoagglutinin (PHA-L) or the retrograde tracer Texas Red-conjugated dextran amine (TRD) into the dorsal and ventral striatum resulted in labeling of striatopallidal fibers and pallidostriatal cell bodies, respectively. DOR1 immunostaining in the pallidum co-localized only with TRD and not PHA-L, whereas pallidal MOR1 immunostaining co-localized with PHA-L and not TRD. These results suggest that pallidal enkephalin release may be modulated by $\mu$ opioid receptors located presynaptically on striatopallidal enkephalinergic neurons and by $\delta$ opioid receptors located postsynaptically on pallidostriatal feedback neurons.

Key words: opioid; striatum; nucleus accumbens; enkephalin; delta receptor; mu receptor; globus pallidus; ventral pallidum
Neurons of the dorsal striatum (caudate putamen) and ventral striatum (nucleus accumbens) exhibit some of the highest concentrations of preproenkephalin mRNA expression in the brain (Yoshikawa et al., 1984; Khachaturian et al., 1985, 1993; Shivers et al., 1986; Harlan et al., 1987; Hurd, 1996). A large proportion of these dorsal and ventral striatal enkephalinergic neurons are medium-sized spiny neurons that project to the globus pallidus (GP) and ventral pallidum (VP), respectively (referred to herein collectively as the pallidum) (Cuello and Paxinos, 1978; Staines et al., 1980; Correa et al., 1981; Del Fiacco et al., 1982; Khachaturian et al., 1983; Groenewegen and Russchen, 1984; Gerfen and Young, 1988). Indeed, very few pallidal neurons synthesize enkephalins (Hökfelt et al., 1977; Johansson et al., 1978; Sar et al., 1978; Finley et al., 1981; Khatchaturian et al., 1983; Williams and Dockray, 1983; Fallon and Leslie, 1986; Harlan et al., 1987; Mansour et al., 1993; Hurd, 1996), indicating that the vast majority of enkephalin in this region is contained in striatopallidal efferent fibers.

Previous studies have implicated the striatopallidal pathways in the rewarding effects of both opiate and psychostimulant drugs (Zito et al., 1985; Hubner and Koob, 1990; Robledo and Koob,

Received April 8, 1997; revised June 26, 1997; accepted July 21, 1997.

This study was supported by United States Public Health Service Grants DA 05010 and DA 09359. M.F.O. was supported by National Research Service Award Predoctoral Fellowship DA 05634 from the National Institute on Drug Abuse and by a Hatos Scholarship. We thank Paul Singh and Phoebe Stewart for assistance with confocal microscopy techniques, Robert Elde and Jeffrey Fein for supply of control peptide sequences, and Diane Martin and Cathey Heron for administrative support

Correspondence should be addressed to Nigel T. Maidment, Department of

Psychiatry and Biobehavioral Sciences, University of California at Los AngelesNeuropsychiatric Institute, 760 Westwood Plaza, Los Angeles, CA 90024-1759.

Copyright (C) 1997 Society for Neuroscience $0270-6474 / 97 / 177471-09 \$ 05.00 / 0$
1993; Gong et al., 1996, 1997). However, the mechanisms governing the release of enkephalins in this system have not been thoroughly investigated. We have previously demonstrated that peripherally administered morphine induced a dose-dependent increase in pallidal enkephalin release (Olive et al., 1995). More recently we showed that $\mu$ and $\delta$ opioid agonists applied locally into the pallidum have bimodal effects on Met- and Leuenkephalin release in this structure, such that low concentrations of these compounds enhance enkephalin release, whereas high concentrations inhibit the release of these peptides (Olive and Maidment, 1996).

Neurotransmitter release can be autoregulated by at least two receptor-mediated mechanisms: receptors located presynaptically on the terminal bouton (i.e., autoreceptors) and receptors located postsynaptically on neurons that have recurrent projections onto the neurotransmitter-releasing neuron (Chesselet, 1984). As evidenced by ligand-binding, immunohistochemical, and mRNA expression data (Mansour et al., 1988, 1993, 1995a,b; Delfs et al., 1994; Bausch et al., 1995; Ding et al., 1996), the pallidum contains low to moderate levels of $\mu$ and $\delta$ receptors, which are thought to be the endogenous receptors for enkephalins (Raynor et al., 1994). The present study used fluorescent neuronal tracing and immunohistochemistry combined with confocal microscopy to determine the presynaptic versus postsynaptic localization of $\mu$ and $\delta$ opioid receptors within the striatopallidal system.

\section{MATERIALS AND METHODS}

Neuronal tracing. All experiments used adult male Sprague Dawley rats (250-350 gm; Harlan, Madison, WI). Tracing of striatopallidal and pallidostriatal pathways was achieved by injecting animals with one of two neuronal tracers under halothane anesthesia in a 1:1 mixture of $\mathrm{O}_{2}$ 


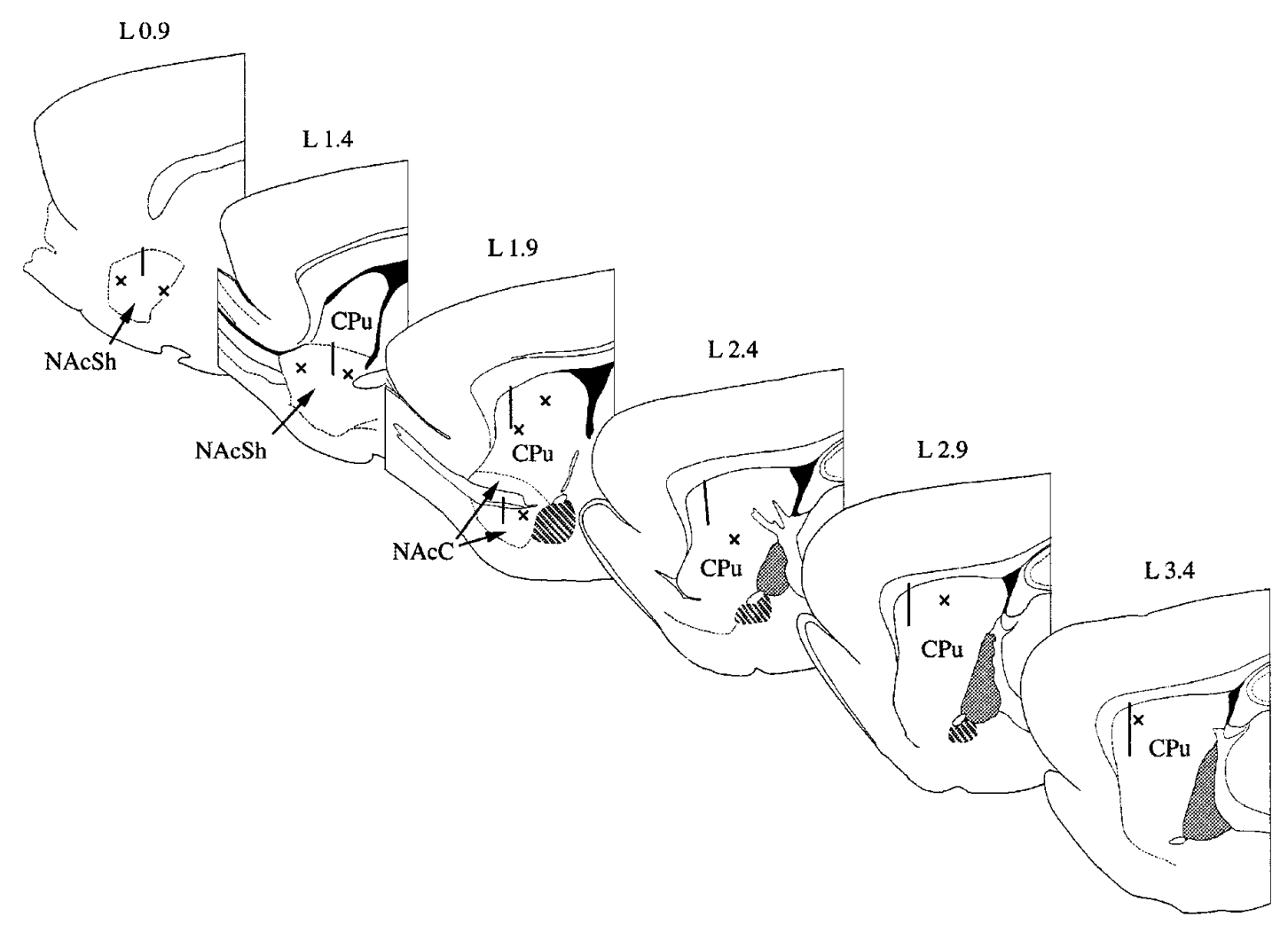

Figure 1. Diagrammatic representation of rat brain sagittal sections showing locations of iontophoretic deposits of PHA-L $(\times)$ and microinjections of TRD (vertical lines). Also shown are regions of the globus pallidus (light gray shading) and ventral pallidum (dark gray hatched shading) examined in the present study. Planes of section are adapted from experimental tissue and the atlas of Paxinos and Watson (1986) and delineated by number of millimeters lateral $(L)$ to the midline. $\mathrm{CPu}$, Caudate-putamen; NAcSh, shell region of nucleus accumbens; NAcC, core region of nucleus accumbens.

and $\mathrm{N}_{2} \mathrm{O}$. For anterograde labeling of striatopallidal projection neurons, Phaseolus vulgaris leucoagglutinin (PHA-L; Vector Laboratories, Burlingame, CA) was unilaterally injected into the dorsal striatum $(n=3)$ or nucleus accumbens $(n=3)$ by iontophoresis according to the method of Gerfen and Sawchenko (1984). Five different locations within each of these two structures were targeted using the following stereotaxic coordinates according to the atlas of Paxinos and Watson (1986): dorsal striatum, anteroposterior (AP), +0.7 to $+1.6 \mathrm{~mm}$; mediolateral $(\mathrm{ML})$, \pm 1.6 to $\pm 3.4 \mathrm{~mm}$; and dorsoventral (DV), -4.6 to $-5.5 \mathrm{~mm}$ from bregma and skull surface; and nucleus accumbens, AP, +1.0 to $+1.7 \mathrm{~mm}$; $\mathrm{ML}, \pm 0.7$ to $\pm 1.9 \mathrm{~mm}$; and $\mathrm{DV},-6.6$ to $-7.4 \mathrm{~mm}$ from bregma and skull surface (Fig. 1). Briefly, glass micropipettes (A-M Systems, Everett, WA) pulled with a vertical microelectrode puller (PE-2; Narishigi Instruments, Tokyo, Japan) to a tip diameter of $10-15 \mu \mathrm{m}$ were back-filled with a solution containing $2.5 \%(\mathrm{w} / \mathrm{v})$ PHA-L in $0.1 \mathrm{M}$ PBS, pH 7.4. Positive current $(5 \mu \mathrm{A})$ was pulsed into the solution via a silver chloride wire at a rate of $7 \mathrm{sec}$ on and $7 \mathrm{sec}$ off for 15-20 min per injection site using a Master-8 pulse generator (A.M.P.I., Jerusalem, Israel) and a World Precision Instruments (New Haven, CT) 160 microiontophoresis controller. After iontophoresis of the tracer solution, the micropipette was left in place for $10 \mathrm{~min}$ before slow withdrawal over a 5 min period. Holes in the skull were covered with bone wax, and animals were killed 4-7 d later.

Retrograde labeling of pallidostriatal neurons was achieved by injecting 200-300 $\mathrm{nl}$ of a $0.5 \%(\mathrm{w} / \mathrm{v})$ solution of Texas Red-conjugated dextran amine (10,000 molecular weight; Molecular Probes, Eugene, OR) (Fritzsch, 1993) in $0.1 \mathrm{~m}$ PBS, $\mathrm{pH} 7.4$, unilaterally into the dorsal striatum ( $n=6$; coordinates: AP, +1.6 ; ML, \pm 2.5 ; and DV,$-5.0 \mathrm{~mm}$ ) or nucleus accumbens $(n=6$; coordinates: AP, $+1.6 ; \mathrm{ML}, \pm 1.4$; and DV, $-7.0 \mathrm{~mm})$ (Fig. 1). Injections were made over a 10 min period using a Hamilton (Reno, NV) $10 \mu \mathrm{l}$ syringe. After injection of the tracer solution, the needle was left in place for a further $10 \mathrm{~min}$ before slow withdrawal over a 5 min period. Because of the large injection volume and to avoid diffusion of the tracer out of the striatum, only one injection was made per animal. Holes in the skull were covered with bone wax, and animals were killed 4-7 d later.
Immunohistochemistry. For all immunohistochemical procedures, animals were deeply anesthetized with Nembutal $(150 \mathrm{mg} / \mathrm{kg}$, i.p.) and perfused with $200 \mathrm{ml}$ of $0.1 \mathrm{M}$ PBS containing $0.1 \%$ heparin, $\mathrm{pH} 7.4$, followed by $800 \mathrm{ml}$ of fixative ( $4 \%$ paraformaldehyde in $0.1 \mathrm{M}$ phosphate buffer, $\mathrm{pH}$ 7.4). Perfusions were performed with ice-cold fixatives in an ambient temperature of $4^{\circ} \mathrm{C}$. Brains were then removed and post-fixed in the same fixative solution at $4^{\circ} \mathrm{C}$ overnight and then transferred to $0.1 \mathrm{M}$ PBS containing $30 \%(\mathrm{w} / \mathrm{v})$ sucrose, $\mathrm{pH} 7.4$, for $48 \mathrm{hr}$. Sagittal sections $(40-50 \mu \mathrm{m})$ were cut on a Jung Frigocut 2800 E cryostat (Leica, Deerfield, IL) and placed into culture plate wells containing $0.1 \mathrm{M} \mathrm{PBS}, \mathrm{pH}$ 7.4 .

All immunohistochemistry was performed on free-floating sagittal sections. Sections were incubated with primary antisera for $24 \mathrm{hr}$ at $4^{\circ} \mathrm{C}$ under gentle agitation in PBS solution containing $0.3 \%$ (v/v) Tween 20 , $1 \%(\mathrm{w} / \mathrm{v})$ bovine serum albumin (fraction $\mathrm{V}$, protease free) and $10 \%$ (v/v) normal goat or donkey serum, $\mathrm{pH} 7.4$ (all chemicals from Sigma, St. Louis, MO). Antisera to the $\delta$ opioid receptor (DOR1), $\mu$ opioid receptor (MOR1), Met- and Leu-enkephalin, PHA-L, and synaptophysin were used in various combinations (see Antisera and Controls for sources and titers).

After incubation with primary antisera, sections were rinsed in PBS and incubated with fluorphore-conjugated secondary antibody in PBS containing $2 \%(\mathrm{v} / \mathrm{v})$ normal goat or donkey serum for $2-3 \mathrm{hr}$ at room temperature under gentle agitation. Sections were then rinsed in PBS containing $0.1 \%(\mathrm{v} / \mathrm{v})$ Tween 20 , mounted onto slides, and coverslipped with a glycerol solution containing ProLong AntiFade reagent (Molecular Probes). Sections were then examined by confocal laser scanning microscopy.

Antisera and controls. A rabbit polyclonal antiserum to residues 3-17 of DOR1 was used at a 1:100 dilution (Incstar, Stillwater, MN; antibody 442E) (Dado et al., 1993, Arvidsson et al., 1995a; Elde et al., 1995; Lai et al., 1996). Preabsorption of this primary antiserum with the synthetic epitope sequence DOR1 3-17 (LVPSARAELQSSPLV; a generous gift of Dr. Robert Elde, University of Minnesota) at $10^{-4} \mathrm{M}$ overnight at $4^{\circ} \mathrm{C}$ was used as a control. A rabbit polyclonal antiserum raised in our laboratory (Sternini et al., 1996) to residues 387-398 of MOR1 was used 
at a 1:20 dilution. Preabsorption of this primary antiserum with the synthetic epitope sequence MOR1 387-398 (LENLEAETAPLP) at $10^{-4} \mathrm{M}$ overnight at $4^{\circ} \mathrm{C}$ was used as a control.

The other primary antisera used were as follows: a monoclonal mouse anti-Met/Leu-enkephalin (Chemicon, Temecula, CA; 1:250 dilution; characterized by Cuello et al., 1984; Kenigsberg and Cuello, 1987), a monoclonal mouse anti-synaptophysin (Sigma; 1:100 dilution; characterized by Devoto and Barnstable, 1987), and a polyclonal goat anti-PHA-L antibody (Vector Laboratories; 1:100 dilution; characterized by Wouterlood et al., 1990).

All secondary antibodies were used at a 1:100 dilution and purchased from Jackson ImmunoResearch Laboratories (West Grove, PA). They consisted of fluorescein isothiocyanate (FITC)-conjugated goat or donkey anti-rabbit IgG and rhodamine-conjugated donkey anti-goat or antimouse IgG heavy and light chain.

Confocal laser microscopy. A detailed description of the simultaneous dual wavelength confocal microscopy method used for our doublelabeling immunofluorescence staining procedures can be found elsewhere (Brelje et al., 1993). Sections were viewed by a Zeiss (Thornwood, NY) 410 confocal laser scanning microscope. FITC was viewed at $488 \mathrm{~nm}$ excitation and with a 515-540 $\mathrm{nm}$ bandpass emission filter, whereas rhodamine and Texas Red were viewed at $568 \mathrm{~nm}$ excitation and with a $590-620 \mathrm{~nm}$ low-pass emission filter. Pixels in images containing overlapping green (FITC) and red (rhodamine and Texas Red) were assigned a yellow (co-localization) color. Images were viewed at a single step size of $0.8 \mu \mathrm{m}$ under low magnification $(10 \times)$ and $0.3-0.5 \mu \mathrm{m}$ under high magnification $(40-100 \times)$. Images were incorporated into Adobe Photoshop (Adobe Systems, San Jose, CA) and printed on FujiFilm Pictro paper (Fuji Photo Film, Tokyo, Japan).

\section{RESULTS}

Cellular distribution of DOR1 immunoreactivity in the pallidum and co-localization with presynaptic markers

The GP and VP were anatomically defined according to the criteria of Paxinos and Watson (1986) as shown in Figure 1. Low to moderate levels of DOR1 staining were evenly distributed throughout the GP (Fig. $2 A$ ) and VP (Fig. 2C). Preincubation of the DOR1 antisera with the peptide sequence to which it was raised (LVPSARAELQSSPLV) at $10^{-4} \mathrm{M}$ for 12-24 hr substantially reduced DOR1 immunostaining (Fig. $2 B$ ). Higher magnification revealed that DOR1 immunoreactivity in the GP was in the form of dense clusters within the cytoplasm of small cell bodies (8-15 $\mu \mathrm{m}$ in diameter) (Fig. $2 D-F)$. No clear enhancement of cell perimeter labeling indicative of plasmalemmal staining was apparent. Similar morphologies were also predominant in the VP (data not shown). Occasionally, diff use cytoplasmic staining for DOR1 could be seen in the soma and proximal fiber processes of cells in the VP (Fig. 2G) and GP (data not shown). Double-labeling experiments showed many of these DOR1immunoreactive cell bodies in the GP and VP to be adjacent to, but not co-localized with, synaptophysin immunoreactivity (Fig. $2 H$ ) and enkephalin (Fig. 2I). No major differences between the GP and VP were observed with regard to DOR1 morphology and co-localization with presynaptic markers. DOR1 staining of fine fiber processes was not observed in the GP or VP with this antiserum.

\section{Cellular distribution of MOR1 immunoreactivity in the pallidum and co-localization with presynaptic markers}

As with DOR1, MOR1 immunostaining was also low to moderate throughout the pallidum. However, unlike DOR1, MOR1 displayed a more heterogeneous distribution in this region. MOR1 immunoreactivity was concentrated in small patches in the dorsocaudal region of the GP (Fig. $3 A$ ) and along the ventral border of the posterior limb of the anterior commissure (Fig. $3 C$ ), with less intense staining in other regions of the pallidum. Preincubation of the MOR1 antisera with the peptide sequence to which it was raised (LENLEAETAPLP) at $10^{-4} \mathrm{M}$ for $12-24 \mathrm{hr}$ substantially reduced MOR1 immunostaining (Fig. 3B). High magnification revealed two different cellular distributions of MOR1 staining. In the more concentrated patches of the GP and VP, fine and diffuse puncta surrounded and formed the outline of what were considered to be small cell bodies $(8-15 \mu \mathrm{m}$ in diameter), which themselves were devoid of MOR1 immunoreactivity (Fig. 3D,E). The other type of staining pattern was an amorphous distribution within the cytoplasm of similar sized cells in the VP (Fig. $3 F$ ) and GP (data not shown). As with DOR1, no clear enhancement of cell perimeter labeling indicative of plasmalemmal staining was apparent. Also similar to DOR1, MOR1 staining of fibrous arborizations could not be observed, although occasional single long fiber processes were seen (data not shown). Double-labeling experiments showed that the fine and diffuse punctate MOR1 immunoreactivity was highly co-localized with synaptophysin in the VP (Fig. 3G) and GP (data not shown). This MOR1 immunoreactivity could also be seen to co-localize with diffuse enkephalin-immunoreactive puncta surrounding small unlabeled cells in the GP (Fig. $3 H$ ) and VP (data not shown). Conversely, cytoplasmic MOR1 staining in the pallidum did not co-localize with synaptophysin (data not shown) or enkephalin (Fig. 3I). No major differences between the GP and VP were observed with regard to MOR1 morphology and co-localization with presynaptic markers.

\section{Neuronal tracing}

To verify that the potential presynaptic or postsynaptic localization of MOR1 or DOR1 immunoreactivity was related to striatopallidal inputs, anterograde labeling of dorsal and ventral striatopallidal neurons was achieved by injection of the specific anterograde tracer PHA-L into the dorsal caudate nucleus or nucleus accumbens (core and shell) (Fig. 1). Labeling of long fiber processes and punctate terminals was seen at low to moderate intensity throughout the GP and VP, with very little or no retrograde labeling of pallidal cell bodies. A limited amount of co-localization of MOR1 immunoreactivity with PHA-L-labeled fiber processes was observed within the GP (Fig. 4A) and VP (not shown). No such co-localization of DOR1 and PHA-L was found in the GP or VP (Fig. 4B).

To determine whether MOR1 or DOR1 immunoreactivity is localized on pallidostriatal feedback neurons, a retrograde dextran amine tracer (TRD) was injected into the dorsal caudate nucleus and nucleus accumbens (core and shell) of a separate set of animals (Fig. 1). This tracer was found to retrogradely label a large number of cell bodies throughout the pallidum. Punctate MOR1 immunoreactivity could be seen to surround such retrogradely labeled neurons, but no co-localization of MOR1 and TRD was seen within the cytoplasm of these cell bodies in the VP (Fig. $4 C$ ) or GP (data not shown). In contrast, DOR1 immunoreactivity could be found in cell bodies that had retrogradely transported the dextran amine to the VP (Fig. 4D) and GP (data not shown), indicating that DOR1 receptors are expressed by pallidostriatal neurons.

\section{DISCUSSION}

We used specific polyclonal antibodies to examine the cellular distribution of MOR1 and DOR1 immunoreactivities in both the striatopallidal and pallidostriatal pathways. Both the GP and VP had low to moderate levels of MOR1 and DOR1 staining, in agreement with other immunohistochemical and in situ hybridization studies (Mansour et al., 1988, 1993, 1995a,b; Churchill et 

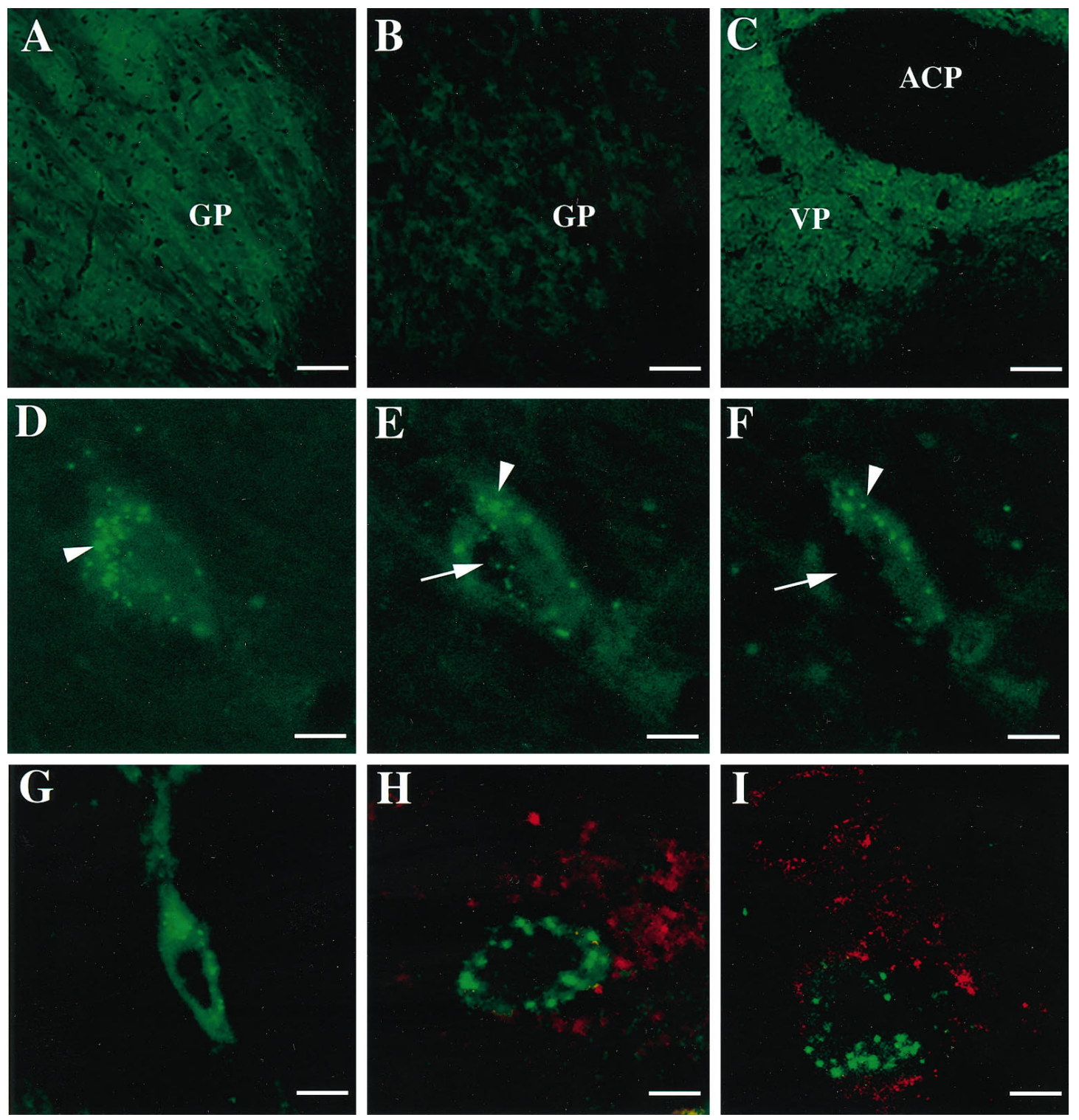

Figure 2. Confocal microscopic images of rat brain sagittal sections showing distribution and morphology of DOR1 immunoreactivity (green) within the pallidum. $A$, Low magnification of DOR1 immunoreactivity in the GP (also see Fig. 1). $B$, Reduction of staining in the GP for DOR1 after preabsorption of the primary antibody with the cognate peptide. $C$, Low magnification of DOR1 immunoreactivity in the VP just beneath the posterior limb of the anterior commissure $(A C P)$ (also see Fig. 1). $D-F$, Morphology of a typical cell body in the GP labeled for DOR1 at a higher magnification, viewed at step sizes of $1.5 \mu \mathrm{m}$. Arrows indicate approximate location of nucleus, and arrowheads demarcate cytoplasmic staining. $G$, Representative image of a DOR1-immunoreactive cell body in the VP with diff use cytoplasmic staining and a small population of more intense vesicular compartment-like structures. Double labeling revealed punctate staining of synaptophysin $(H, r e d)$ and enkephalin $(I$, red $)$ surrounding DOR1-labeled cell bodies (in GP and VP, respectively) with no apparent co-localization. Scale bars: $A, B, 250 \mu \mathrm{m} ; C, 100 \mu \mathrm{m} ; D-I, 5 \mu \mathrm{m}$.

al., 1990; Delfs et al., 1994; Bausch et al., 1995; Ding et al., 1996; Moriwaki et al., 1996). The regional distribution of MOR1 and DOR1 immunoreactivities within the pallidum was also consistent with the findings of other investigators. Thus, a diffuse and relatively homogeneous distribution of DOR1 was observed throughout the GP and VP (Mansour et al., 1994a, 1995b). MOR1 immunoreactivity was heterogeneously distributed in these structures, with a greater clustering of MOR1-stained cells in the caudal regions of the GP (Mansour et al., 1994a,b, 1995b; Ding et al., 1996) and rostrodorsal parts of the VP (Churchill et al., 1990; Delfs et al., 1994; Mansour et al., 1994b).

Many studies have localized $\mu$ and $\delta$ opioid receptors presynaptically and postsynaptically with respect to enkephalinergic terminals in other regions of the CNS at the light microscopic
(Arvidsson et al., 1995a,b; Guttenberg et al., 1996) and electron microscopic levels (Cheng et al., 1995, 1996a,b; Svingos et al., 1995, 1996; van Bockstaele et al., 1996; Wang et al., 1996). Studies examining presynaptic versus postsynaptic localization of opioid receptors in the striatopallidal system have used autoradiographic binding techniques after striatal lesions. One group found no change in ventral pallidal $\mu$ receptor binding after lesions of the ventral striatum (Churchill et al., 1990), whereas others found significant decreases in both pallidal $\mu$ and $\delta$ receptor binding after lesions of the dorsal striatum (Abou-Khalil et al., 1984; Waksman et al., 1987). However, changes in radiolabeled ligand binding after lesions are difficult to interpret with respect to precise presynaptic or postsynaptic localization of the receptor of interest. Lesion-induced increases in the number of postsynaptic 

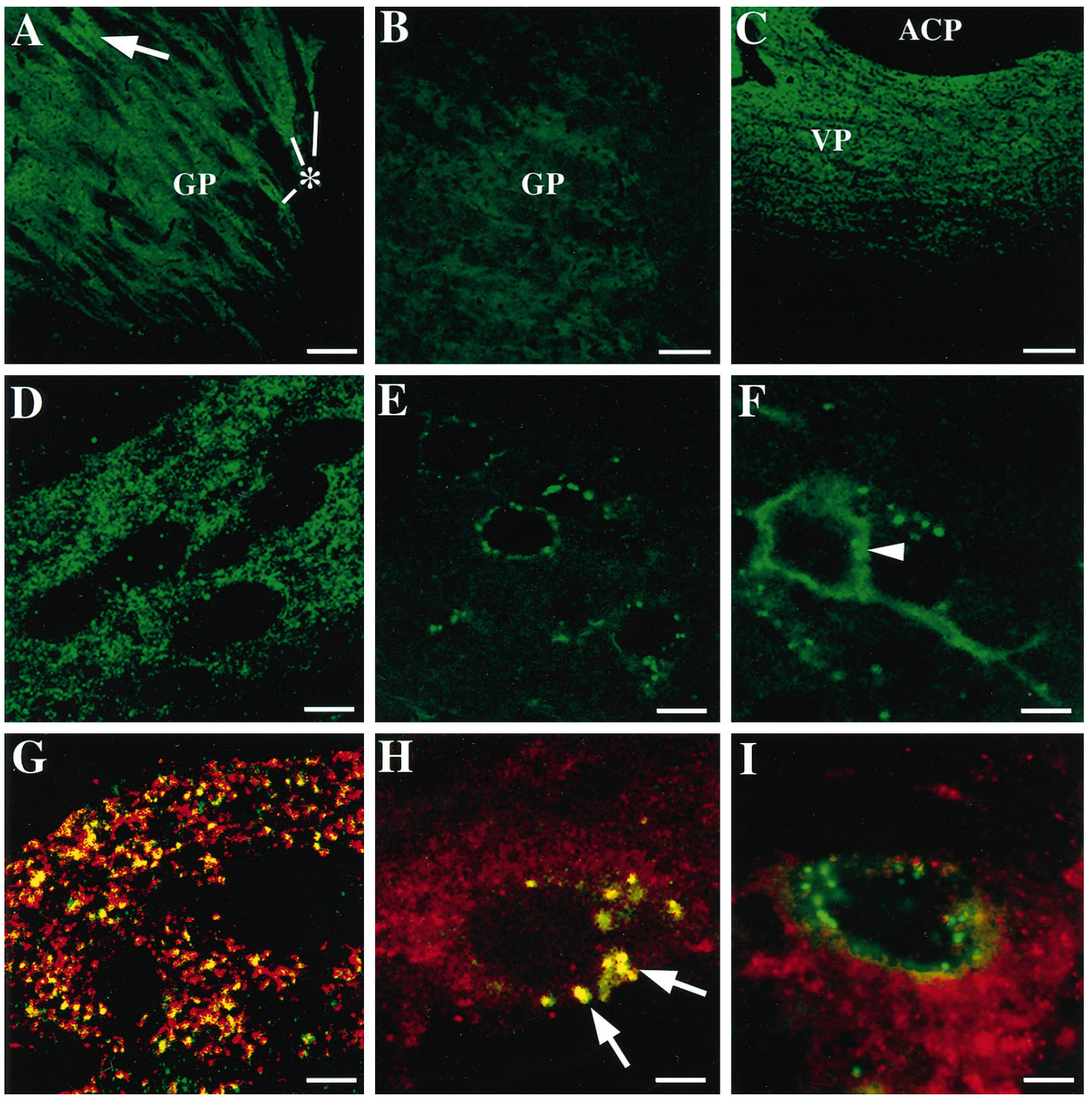

Figure 3. Confocal microscope images of rat brain sagittal sections showing distribution and morphology of MOR1 immunoreactivity (green) within the pallidum. $A$, Low magnification of the GP. Note the clusters of higher intensity of MOR1 staining along the dorsocaudal border of the globus pallidus (asterisk) and a patch of MOR1 immunoreactivity in the striatum (arrow). B, Reduction of staining for MOR1 after preabsorption of the primary antibody with the cognate peptide. $C$, Low magnification of the VP just beneath the posterior limb of the anterior commissure $(A C P)$ (also see Fig. 1). Note the higher intensity of MOR1 staining along the dorsal rim of the VP. $D, E$, High magnification showing punctate MOR1 staining surrounding spherical entities in the subcommisural ventral pallidal region $(D)$ and globus pallidus $(E)$. $F$, Typical morphology of cell bodies in the VP with cytoplasmic (arrowhead) staining of MOR1. G, High magnification showing high degree of co-localization (yellow) of MOR1 (green) with synaptophysin (red) immunoreactivity in the subcommisural VP. H, Co-localization (yellow, arrows) of MOR1 (green) with enkephalin (red) surrounding a putative cell body in the GP. I, Lack of co-localization of cytoplasmic MOR1 staining (green) in the GP with synaptophysin (red). Scale bars: $A, B, 250 \mu \mathrm{m} ; C, 100 \mu \mathrm{m}$; $D-I, 5 \mu \mathrm{m}$.

receptors attributable to receptor upregulation or, conversely, decreases attributable to trans-synaptic degeneration could also account for the observed changes (or lack thereof) in radioligand binding. The increased resolution offered by immunohistochemical localization of receptors combined with co-localization of presynaptic and postsynaptic markers circumvents these limitations.

We have shown a discrete presynaptic localization of $\mu$ opioid receptors within the striatopallidal projection systems, as evidenced by MOR1 immunoreactivity in the GP and VP that surrounded cell body-shaped structures and showed colocalization with synaptophysin, enkephalin, and anterogradely labeled striatopallidal fibers. Other investigators have also found $\mu$ receptors to be presynaptic on enkephalinergic terminals in the striatum and nucleus accumbens (Svingos et al., 1995, 1996; Guttenberg et al., 1996). It is therefore likely that MOR1 serves as a presynaptic autoreceptor regulating the release of enkephalins from striatopallidal projection neurons. Given the predominant inhibitory effects of opiates on neurotransmitter release via $\mathrm{G}_{\mathrm{o}}$ - or $\mathrm{G}_{\mathrm{i}}$-protein-coupled mechanisms (see Mulder and Schoffelmeer, 1993; Huang, 1995; Sarne et al., 1996), such receptors may mediate the inhibitory effects of high concentrations of $\mu$ agonists on enkephalin release observed in microdialysis studies conducted in our laboratory (Olive and Maidment, 1996). It should also be noted, however, that activation of presynaptic $\mu$ receptors has been demonstrated to mediate stimulatory effects on enkephalin release under certain circumstances, particularly at 

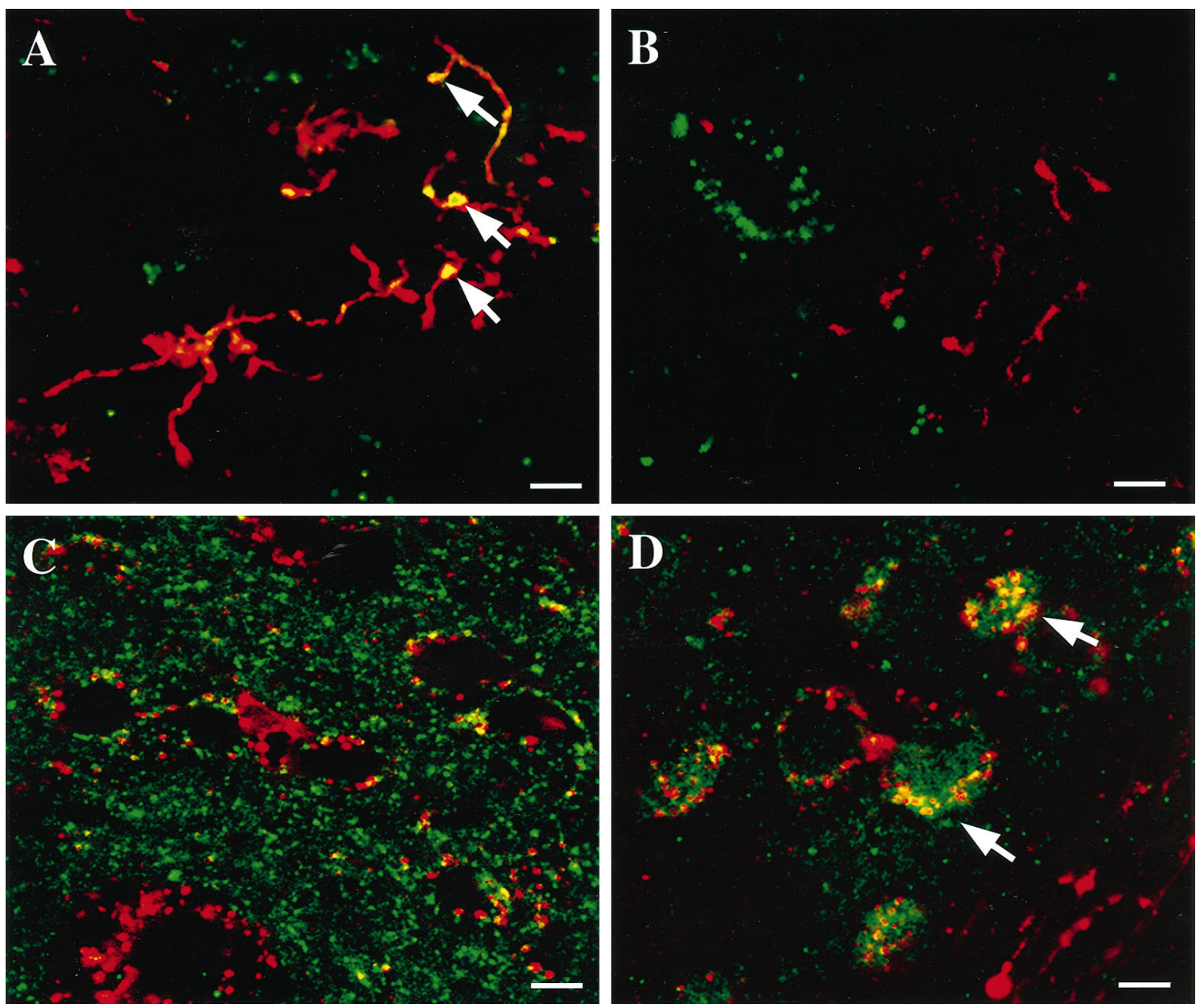

Figure 4. Confocal microscopic images showing co-localization of neuronal tracers with MOR1 and DOR1. A, Co-localization (yellow, arrows) of MOR1 immunoreactivity ( green) with PHA-L-labeled striatopallidal fibers (red) in the globus pallidus. B, Lack of co-localization of DOR1 ( green) on PHA-L-labeled striatopallidal fibers (red) in the globus pallidus. $C$, Lack of co-localization of TRD (red) with punctate MOR1 immunoreactivity ( green) in the ventral pallidum. $D$, Co-localization (yellow, arrows) of DOR1 immunoreactivity (green) in TRD-labeled (red) pallidostriatal cell bodies. Scale bars: $A, 20 \mu \mathrm{m} ; B-D, 10 \mu \mathrm{m}$.

low agonist concentrations, possibly via coupling to $\mathrm{G}_{\mathrm{s}}(\mathrm{Xu}$ et al., 1989; Gintzler and Xu, 1991). The possibility that these presynaptic receptors mediate the stimulatory effects of low concentrations of morphine on pallidal enkephalin release cannot, therefore, be ruled out (Olive et al., 1995; Olive and Maidment, 1996). It should also be noted that studies at the electron microscopic level are needed to confirm the precise presynaptic ultrastructural localization of $\mu$ receptors within the pallidum.

$\mu$ opioid receptors were also localized to postsynaptic structures within the pallidum but, unlike DOR1, did not appear to be present on pallidostriatal neurons, as evidenced by lack of colocalization with TRD. (It should be noted that our data do not entirely eliminate the possibility that MOR1 is expressed in pallidostriatal neurons that were not labeled by the TRD injections.) Therefore, if postsynaptic $\mu$ receptors are mediating the observed stimulatory and/or inhibitory effects of locally administered morphine on enkephalin release in the pallidum (Olive and Maidment, 1996), it is necessary to invoke polysynaptic feedback mechanisms. In this regard, electrophysiological studies have reported both excitatory and inhibitory responses of VP neurons to microiontophoretic application of morphine (Napier et al., 1992; Chrobak and Napier, 1993; Mitrovic and Napier, 1995; Johnson and Napier, 1997) and primarily inhibitory responses of GP neurons (Huffman and Felpel, 1981; Stone, 1983; Napier et al., 1983, 1992).

We failed to find evidence of a presynaptic localization of DOR1 immunoreactivity in the GP and VP. No staining of fibers or varicosities was apparent, and similarly, no colocalization with synaptophysin or enkephalin immunoreactivity was observed. Previous immunohistochemical studies using the same (Dado et al., 1993; Arvidsson et al., 1995a) or different (Cheng et al., 1995; Svingos et al., 1995) antisera have demonstrated that $\delta$ receptors can exist presynaptically in other regions of the nervous system. Indeed, we did find evidence of a presynaptic localization of DOR1 in the median eminence and in the dorsal horn of the spinal cord (data not shown), in agreement with the initial characterization of this antiserum (Dado et al., 1993; Arvidsson et al., 1995a). This suggests that the $\delta$ receptor agonist-induced stimulation of pallidal enkephalin release revealed by microdialysis (Olive and Maidment, 1996) is mediated by activation of a positive feedback loop. The demonstration of a discrete postsynaptic localization of $\delta$ opioid receptors in the GP and VP within cell bodies of neurons retrogradely labeled by injection of TRD into the dorsal and ventral striatum is consistent with the hypothesis that such feedback may be direct. Considerable anatomical and electrophysiological evidence exists for a direct pathway from the 
pallidum to the striatum (Staines et al., 1981; Staines and Fibiger, 1984; Walker et al., 1989; Hakan et al., 1992; Nambu and Llinás, 1997), which uses GABA as a neurotransmitter (Churchill and Kalivas, 1994; Rajakumar et al., 1994) and which is thought to play a role in the modulation of striatopallidal circuits (Kuo and Chang, 1992; Rajakumar et al., 1994; Spooren et al., 1996). Thus, inhibition of such inhibitory GABAergic feedback neurons via $\delta$ opioid receptor activation (Mitrovic and Napier, 1995) would be one mechanism whereby locally administered $\delta$ agonists could increase enkephalin release in the pallidum.

Although the dorsal and ventral striatopallidal systems share many anatomical and functional qualities (see Haber et al., 1985; Heimer et al., 1985; Alheid and Heimer, 1988), some differences between these two pathways do exist, for example, with regard to the postsynaptic effects of opioids in the GP and VP cited above. Such differences could theoretically be attributable to differences in presynaptic versus postsynaptic localization of $\mu$ and $\delta$ opioid receptors between the GP and VP or to differences in opioid receptor density or signal transduction mechanisms between the GP and VP. However, we failed to find any obvious differences between the GP and VP in terms of the general morphology of MOR1 and DOR1 staining and co-labeling with presynaptic markers. Deposits of anterograde and retrograde tracer were made into the caudate nucleus and into both the core and shell of the nucleus accumbens, but we found no differences with regard to colocalization of such markers with either MOR1 or DOR1 between the GP and VP. More extensive comparison of these two similar but nevertheless disparate opioidergic striatal output pathways is warranted.

Taken together, the results of the current study and our parallel pharmacological experiments suggest that pallidal enkephalin release may be modulated by $\mu$ opioid receptors located presynaptically on striatopallidal enkephalinergic fibers and by $\delta$ opioid receptors located postsynaptically to these enkephalinergic terminals on feedback neurons that project to the striatum. The possibility also exists that $\mu$ receptors located postsynaptically on pallidal neurons contribute to a polysynaptic feedback loop regulating pallidal enkephalin release. Further studies at the electron microscopic level are warranted to examine the ultrastructural localization of $\mu$ and $\delta$ opioid receptors in striatopallidal pathways.

\section{REFERENCES}

Abou-Khalil B, Young AB, Penney JB (1984) Evidence for the presynaptic localization of opiate binding sites on striatal efferent fibers. Brain Res 323:21-29.

Alheid GF, Heimer L (1988) New perspectives in basal forebrain organization of special relevance for neuropsychiatric disorders: the striatopallidal, amygdaloid, and corticopetal components of substantia innominata. Neuroscience 27:1-39.

Arvidsson U, Dado RJ, Riedl M, Lee J-H, Law PY, Loh HH, Elde R, Wessendorf MW (1995a) $\delta$-Opioid receptor immunoreactivity: distribution in brainstem and spinal cord, and relationship to biogenic amines and enkephalin. J Neurosci 15:1215-1235.

Arvidsson U, Riedl M, Chakrabarti S, Lee J-H, Nakano AH, Dado RJ, Loh HH, Law PY, Wessendorf MW, Elde R (1995b) Distribution and targeting of a $\mu$-opioid receptor (MOR1) in brain and spinal cord. J Neurosci 15:3328-3341.

Bausch SB, Patterson TA, Appleyard SM, Chavkin C (1995) Immunocytochemical localization of delta opioid receptors in mouse brain. J Chem Neuroanat 8:175-189.

Brelje TC, Wessendorf MW, Sorenson RL (1993) Multicolor laser scanning confocal immunofluorescence microscopy: practical applications and limitations. Methods Cell Biol 38:97-181.

Cheng PY, Svingos AL, Wang H, Clarke CL, Jenab S, Beczkowska IW, Inturrisi CE, Pickel VM (1995) Ultrastructural immunolabeling shows prominent presynaptic vesicular localization of $\delta$-opioid receptor within both enkephalin- and nonenkephalin-containing axon terminals in the superficial layers of the rat cervical spinal cord. J Neurosci 15:5976-5988.

Cheng PY, Liu-Chen LY, Chen C, Pickel VM (1996a) Immunolabeling of mu opioid receptors in the rat nucleus of the solitary tract: extrasynaptic plasmalemmal localization and association with Leu5enkephalin. J Comp Neurol 371:522-536.

Cheng PY, Moriwaki A, Wang JB, Uhl GR, Pickel VM (1996b) Ultrastructural localization of $\mu$-opioid receptors in the superficial layers of the rat cervical spinal cord: extrasynaptic sites localization and proximity to leu5-enkephalin. Brain Res 731:141-154.

Chesselet M-F (1984) Presynaptic regulation of neurotransmitter release in the brain: facts and hypothesis. Neuroscience 12:347-375.

Chrobak JJ, Napier TC (1993) Opioid and GABA modulation of accumbens-evoked ventral pallidal activity. J Neural Transm 93:123-143.

Churchill L, Kalivas PW (1994) A topographically organized gammaaminobutyric acid projection from the ventral pallidum to the nucleus accumbens in the rat. J Comp Neurol 345:579-595.

Churchill L, Dilts RP, Kalivas PW (1990) Changes in $\gamma$-aminobutyric acid, $\mu$-opioid and neurotensin receptors in accumbens-pallidal projection after discrete quinolinic acid lesions of the nucleus accumbens. Brain Res 511:41-54.

Correa FMA, Innis RB, Hester LD, Snyder SH (1981) Diffuse enkephalin innervation from caudate to globus pallidus. Neurosci Lett 25:63-68.

Cuello AC, Paxinos G (1978) Evidence for a long leu-enkephalin striopallidal pathway in rat brain. Nature 271:178-180.

Cuello AC, Milstein C, Couture R, Wright B, Priestly JV, Jarvis J (1984) Characterization and immunocytochemical application of monoclonal antibodies against enkephalins. J Histochem Cytochem 32:947-957.

Dado RJ, Law PY, Loh HH, Edle R (1993) Immunofluorescent identification of a delta $(\delta)$-opioid receptor on primary afferent nerve terminals. NeuroReport 5:341-344.

Del Fiacco M, Paxinos G, Cuello AC (1982) Neostriatal enkephalinimmunoreactive neurons project to the globus pallidus. Brain Res 231:1-17.

Delfs JM, Kong H, Mestek A, Chen Y, Yu L, Reisine T, Chesselet M-F (1994) Expression of mu opioid receptor mRNA in rat brain: an in situ hybridization study at the single cell level. J Comp Neurol 345:46-68.

Devoto SH, Barnstable CJ (1987) SVP38: a synaptic vesicle protein whose appearance correlates closely with synaptogenesis in the rat nervous system. Ann NY Acad Sci 493:493-496.

Ding Y-Q, Kaneko T, Nomura S, Mizuno N (1996) Immunohistochemical localization of $\mu$-opioid receptor in the central nervous system of the rat. J Comp Neurol 367:375-402.

Elde R, Arvidsson U, Riedl M, Vulchanova L, Lee J-H, Dado R, Nakano A, Chakrabarti S, Zhang X, Loh HH, Law PY, Hokfelt T, Wessendorf M (1995) Distribution of neuropeptide receptors-new views of peptidergic neurotransmission made possible by antibodies to opioid receptors. Ann NY Acad Sci 757:390-404.

Fallon JH, Leslie FM (1986) Distribution of dynorphin and enkephalin peptides in rat brain. J Comp Neurol 249:293-336.

Finley JCW, Maderdrut JL, Petrusz P (1981) The immunocytochemical localization of enkephalin in the central nervous system of the rat. J Comp Neurol 198:541-565.

Fritzsch B (1993) Fast axonal diffusion of 3000 molecular weight dextran amines. J Neurosci Methods 50:95-103.

Gerfen CR, Sawchenko PE (1984) An anterograde neuroanatomical tracing method that shows the detailed morphology of neurons, their axons and terminals: immunohistochemical localization of an axonally transported plant lectin, Phaseolus vulgaris-leucoagglutinin (PHA-L). Brain Res 290:219-238.

Gerfen CR, Young III WS (1988) Distribution of striatonigral and striatopallidal peptidergic neurons in both patch and matrix compartments: an in situ hybridization histochemistry and fluorescent retrograde tracing study. Brain Res 460:161-167.

Gintzler AR, Xu H (1991) Different G proteins mediate the opioid inhibition or enhancement of evoked [5-methionine]enkephalin release. Proc Natl Acad Sci USA 88:4741-4745.

Gong WH, Neill D, Justice JB (1996) Conditioned place preference and locomotor activation produced by injection of psychostimulants into ventral pallidum. Brain Res 707:64-74.

Gong WH, Neill D, Justice JB (1997) 6-Hydroxydopamine lesion of 
ventral pallidum blocks acquisition of place preference conditioning to cocaine. Brain Res 754:103-112.

Groenewegen HJ, Russchen FT (1984) Organization of the efferent projections of the nucleus accumbens to pallidal, hypothalamic, and mesencephalic structures: a tracing and immunohistochemical study in the cat. J Comp Neurol 223:347-367.

Guttenberg ND, Klop H, Minami M, Satoh M, Voorn P (1996) Colocalization of $\mu$ opioid receptor is greater with dynorphin than enkephalin in rat striatum. NeuroReport 7:2119-2124.

Haber SN, Groenewegen HJ, Grove EA, Nauta WJ (1985) Efferent connections of the ventral pallidum: evidence of a dual striatopallidof ugal pathway. J Comp Neurol 235:322-335.

Hakan RL, Berg GI, Henriksen SJ (1992) Electrophysiological evidence for reciprocal connectivity between the nucleus accumbens septi and ventral pallidal region. Brain Res 581:344-350.

Harlan RE, Shivers BD, Romano GJ, Howells RD, Pfaff DW (1987) Localization of preproenkephalin mRNA in rat brain and spinal cord by in situ hybridization. J Comp Neurol 258:159-184.

Heimer L, Alheid GF, Zaborszky L (1985) The basal ganglia. In: The rat nervous system, Vol 1, Forebrain and midbrain (Paxinos G, ed), pp 37-65. Orlando, FL: Academic.

Hökfelt T, Elde R, Johansson O, Terenius L, Stein L (1977) The distribution of enkephalin-immunoreactive cell bodies in the rat central nervous system. Neurosci Lett 5:25-31.

Huang L-YM (1995) Cellular mechanisms of excitatory and inhibitory actions of opioids. In: Pharmacology of opioid peptides (Tseng LF, ed), pp 131-149. Singapore: Harwood Academic.

Hubner CB, Koob GF (1990) The ventral pallidum plays a role in mediating cocaine and heroin self-administration in the rat. Brain Res 508:20-29.

Huffman RD, Felpel LP (1981) A microiontophoretic study of morphine on single neurons in the rat globus pallidus. Neurosci Lett 22:195-199.

Hurd YL (1996) Differential messenger RNA expression of prodynorphin and proenkephalin in the human brain. Neuroscience 72:767-783.

Johansson O, Hökfelt T, Elde RP, Schultzberg M, Terenius L (1978) Immunohistochemical distribution of enkephalin neurons. Adv Biochem Psychopharmacol 18:51-70.

Johnson PI, Napier TC (1997) Morphine modulation of GABA- and glutamate-induced changes of ventral pallidal neuronal activity. Neuroscience 77:187-197.

Kenigsberg RL, Cuello AC (1987) Role of immunology in defining transmitter-specific neurons. Immunol Rev 100:279-306.

Khachaturian H, Lewis ME, Hollt V, Watson SJ (1983) Telencephalic enkephalinergic systems in the rat brain. J Neurosci 3:844-855.

Khachaturian H, Lewis ME, Schäfer MK-H, Watson SJ (1985) Anatomy of the CNS opioid system. Trends Neurosci 8:111-119.

Khachaturian H, Schaefer MKH, Lewis ME (1993) Anatomy and function of the endogenous opioid systems. In: Opioids I, Handbook of experimental pharmacology, Vol 104 (Herz A, ed), pp 471-497. New York: Springer.

Kuo H, Chang HT (1992) Ventral pallido-striatal pathway in the rat brain: a light and electron microscopic study. J Comp Neurol 321:626-636.

Lai J, Riedl M, Stone LS, Arvidsson U, Bilsky EJ, Wilcox GL, Elde R, Porreca F (1996) Immunofluorescence analysis of antisense oligodeoxynucleotide-mediated "knock-down" of the mouse $\delta$ opioid receptor in vitro and in vivo. Neurosci Lett 213:205-208.

Mansour A, Khachaturian H, Lewis ME, Akil H, Watson SJ (1988) Anatomy of CNS opioid receptors. Trends Neurosci 11:308-314.

Mansour A, Thompson RC, Akil H, Watson SJ (1993) Delta opioid receptor mRNA distribution in the brain: comparison to delta receptor binding and proenkephalin mRNA. J Chem Neuroanat 6:351-362.

Mansour A, Fox CA, Burke S, Meng F, Thompson RC, Akil H, Watson SJ (1994a) Mu, delta, and kappa opioid receptor mRNA expression in the rat CNS: an in situ hybridization study. J Comp Neurol 350:412-438.

Mansour A, Fox CA, Thompson RC, Akil H, Watson SJ (1994b) $\mu$-Opioid receptor mRNA expression in the rat CNS: comparison to $\mu$-receptor binding. Brain Res 643:245-265.

Mansour A, Fox CA, Akil H, Watson SJ (1995a) Opioid-receptor mRNA expression in the rat CNS: anatomical and functional implications. Trends Neurosci 18:22-29.

Mansour A, Fox CA, Burke S, Akil H, Watson SJ (1995b) Immunohistochemical localization of the cloned $\mu$ opioid receptor in the rat CNS. J Chem Neuroanat 8:283-305.
Mitrovic I, Napier TC (1995) Electrophysiological demonstration of mu, delta and kappa opioid receptors in the ventral pallidum. J Pharmacol Exp Ther 272:1260-1270.

Moriwaki A, Wang J-B, Svingos A, van Bockstaele E, Cheng P, Pickel V, Uhl GR (1996) $\mu$ opiate receptor immunoreactivity in rat central nervous system. Neurochem Res 21:1315-1331.

Mulder AH, Schoffelmeer ANM (1993) Multiple opioid receptors and presynaptic modulation of neurotransmitter release in the brain. In: Opioids I, Handbook of experimental pharmacology, Vol 104 (Herz A, ed), pp 125-144. New York: Springer.

Nambu A, Llinás R (1997) Morphology of globus pallidus neurons: its correlation with electrophysiology in guinea pig brain slices. J Comp Neurol 377:85-94.

Napier TC, Pirch JH, Strahlendorf HK (1983) Naloxone antagonizes striatally-induced suppression of globus pallidus unit activity. Neuroscience 9:53-59.

Napier TC, Chrobak JJ, Yew J (1992) Systemic and microintophoretic administration of morphine differentially effect ventral pallidum/substantia innominata neuronal activity. Synapse 12:214-219.

Olive MF, Maidment NT (1996) Excitatory and inhibitory effects of mu and delta opioid agonists on pallidal enkephalin release in vivo. In: Monitoring molecules in neuroscience, Proceedings of the 7th International Conference on In Vivo Methods (Gonzales-Mora JL, Borges R, Mas M, eds) pp, 195-196. Santa Cruz dé Tenerife, Spain: University of La Laguna.

Olive MF, Bertolucci M, Evans CJ, Maidment NT (1995) Microdialysis reveals a morphine-induced increase in pallidal opioid peptide release. NeuroReport 6:1093-1096.

Paxinos G, Watson C (1986) The rat brain in stereotaxic coordinates, Ed 2. New York: Academic.

Rajakumar N, Elisevich K, Flumerfelt BA (1994) The pallidostriatal projection in the rat: a recurrent inhibitory loop? Brain Res 651:332-336.

Raynor K, Kong H, Chen Y, Tasuda K, Yu L, Bell GI, Reisine T (1994) Pharmacological characterization of the cloned $\kappa$-, $\delta$-, and $\mu$-opioid receptors. Mol Pharmacol 45:330-334.

Robledo P, Koob GF (1993) Two discrete nucleus accumbens projection areas differentially mediate cocaine self-administration in the rat. Behav Brain Res 55:159-166.

Sar M, Stumpf WE, Miller RJ, Chang K-J, Cuatrecasas P (1978) Immunohistochemical localization of enkephalin in rat brain and spinal cord. J Comp Neurol 182:17-28.

Sarne Y, Fields A, Keren O, Gafni M (1996) Stimulatory effects of opioids on transmitter release and possible cellular mechanisms: overview and original results. Neurochem Res 21:1353-1361.

Shivers BD, Harlan RE, Romano GJ, Howells RD, Pfaff DW (1986) Cellular localization of preproenkephalin mRNA in rat brain: gene expression in the caudate-putamen and cerebellar cortex. Proc Natl Acad Sci USA 83:6221-6225.

Spooren WPJM, Lynd-Balta E, Mitchell S, Haber SN (1996) Ventral pallidostriatal pathway in the monkey: evidence for modulation of basal ganglia circuits. J Comp Neurol 370:295-312.

Staines WA, Fibiger HC (1984) Collateral projections of the rat globus pallidus to the striatum and substantia nigra. Exp Brain Res 56:217-220.

Staines WA, Nagy JI, Vincent SR, Fibiger HC (1980) Neurotransmitters contained in the efferents of the striatum. Brain Res 194:391-402.

Staines WA, Atmadja S, Fibiger HC (1981) Demonstration of a pallidostriatal pathway by retrograde transport of HRP-labeled lectin. Brain Res 206:446-450.

Sternini C, Spann M, Anton B, Keith Jr DE, Bunnett NW, von Zastrow M, Evans C, Brecha NC (1996) Agonist-selective endocytosis of $\mu$ opioid receptor by neurons in vivo. Proc Natl Acad Sci USA 93:9241-9246.

Stone TW (1983) A comparison of the effects of morphine, enkephalin, kyotorphin and D-phenylalanine on rat central neurones. Br J Pharmacol 79:305-312.

Svingos AL, Cheng PY, Clarke CL, Pickel VM (1995) Ultrastructural localization of $\delta$-opioid receptor and Met5-enkephalin immunoreactivity in rat insular cortex. Brain Res 700:25-39.

Svingos AL, Moriwaki A, Wang JB, Uhl GR, Pickel VM (1996) Ultrastructural immunocytochemical localization of $\mu$-opioid receptors in rat nucleus accumbens: extrasynaptic plasmalemmal distribution and association with Leu5-enkephalin. J Neurosci 16:4162-4173.

van Bockstaele EJ, Colago EEO, Moriwaki A, Uhl GR (1996) Mu-opioid 
receptor is located on the plasma membrane of dendrites that receive asymmetric synapses from axon terminals containing leucine-enkephalin in the rat nucleus locus coeruleus. J Comp Neurol 376:65-74.

Waksman G, Hamel E, Delay-Goyet P, Roques BP (1987) Neutral endopeptidase-24.11, $\mu$ - and $\delta$-opioid receptors after selective brain lesions: an autoradiographic study. Brain Res 436:205-216.

Walker RH, Arbuthnott GW, Wright AK (1989) Electrophysiological and anatomical observations concerning the pallidostriatal pathway in the rat. Exp Brain Res 74:303-310.

Wang H, Moriwaki A, Wang JB, Uhl GR, Pickel VM (1996) Ultrastructural immunocytochemical localization of $\mu$ opioid receptors and $\mathrm{Leu}^{5}$ enkephalin in the patch compartment of the rat caudate-putamen nucleus. J Comp Neurol 375:659-674.

Williams RG, Dockray GJ (1983) Distribution of enkephalin-related peptides in rat brain: immunohistochemical studies using antisera to enkephalin and Met-enkephalin $\mathrm{Arg}^{6} \mathrm{Phe}^{7}$. Neuroscience 9:563-586.

Wouterlood FG, Goede PH, Groenewegen HJ (1990) The in situ detectability of the neuroanatomical tracer Phaseolus vulgaris-leucoagglutinin (PHA-L). J Chem Neuroanat 3:11-18.

Xu H, Smolens I, Gintzler AR (1989) Opioids can enhance and inhibit the electrically evoked release of methionine-enkephalin. Brain Res 504:36-42.

Yoshikawa K, Williams C, Sabol SL (1984) Rat brain preproenkephalin mRNA. cDNA cloning, primary structure, and distribution in the central nervous system. J Biol Chem 259:14301-14308.

Zito KA, Vickers G, Roberts DCS (1985) Disruption of cocaine and heroin self-administration following kainic acid lesions of the nucleus accumbens. Pharmacol Biochem Behav 23:1029-1036. 